\title{
Blogger: New Media Relations Strategy in Corporate Communication
}

\author{
$1^{\text {st }}$ Farida Hariyati* \\ Department of Communication \\ Faculty of Social and Political Sciences \\ Universitas Muhammadiyah Prof. DR. HAMKA \\ Jakarta, Indonesia \\ farida12014@gmail.com
}

\author{
$2^{\text {nd }}$ Yulia Rahmawati \\ Department of Communication \\ Faculty of Social and Political Sciences \\ Universitas Muhammadiyah Prof. DR. HAMKA \\ Jakarta, Indonesia \\ yr.yuliarahmawati@gmail.com
}

\begin{abstract}
The presence of the internet that result to new media such as social media provides a new trend in conveying corporate's messages to the audience. This new trend has brought a transformation in the context of corporate communication to create a new strategy by making bloggers as media partners for endorsement. Engagement with bloggers is part of the corporate's media relations strategy which currently becomes more increasingly complex due to the emergence of diverse and real time media platform choices. In fostering relations with the media, corporates must have a strategy in choosing the right channel. Data collection was conducted through interviews with selected informants with the criteria: Blogger, Blogger Community Founder, Blogger Agency, and Corporate Communication. The results of this study reveal a transformation from old media relations to new media relations through selected bloggers who become corporate's media partners. Selected and effective bloggers in endorsement are those who meet the criteria needed by the corporate, such as quality of writing, interactivity in social media, the ability in Search Engine Optimization (SEO) and Page Rank.
\end{abstract}

Keywords: blogger, media relations, endorsement, corporate communication

\section{INTRODUCTION}

In this technological era, the challenges of corporate communication practitioners in the digital age are becoming more complex due to various factors: (1) increased interactivity; (2) communication is a real time response, there is no delay; (3) the role of media relations is getting more complex because there are so many media choices (multiplatform); and (4) the occurrence of disruptive communication so that certain intelligence and perseverance are needed to select it properly. The emergence of these various media platforms encourages the emergence of business disruption that cannot be avoided so corporates need to engage in new media relations which can be implemented by actively approaching social media reporters (bloggers) and by offering unique (distinctive) ways for them to tell about the company. [1]

Media relation is a complex process involving an organization's media relations strategy, media relations professionals, and journalists, editors, and media enterprises [2]. Zoch and Molleda (2006) proposed a model of media relations focussing mainly on the organizational process of creating media relations programs or campaigns. [3]. They view media relations as a strategic function of public relations without taking into account the mass media system and its influence on strategic media relations [4]

New communication technologies continue to change how media relations is being practiced, with vibrant digital platforms increasing public relations specialists' opportunities to engage in solicited activities (crowd sourcing) known as media catching, "a reversal of the traditional media relations' communication patterns" [5]. Simply, a reporter reaches out to sources to request content (information, insights or comments) for a specific story through a media request service. Essentially, this approach is earned media, or a strategy to achieve publicity through such organic methods as customer reviews, blog posts, and newspaper stories. In fact, media catching is considered one of the forms of strategic mediation, a new practice that supplements or replaces old media relations in the digital era [4].

In the current communication disruption, what has come to be called a media shift, from mass mediated communication to switch to own produced and delivered content by strategic communicators [4]. Organizations tend to make use of different forms of media when they are about to communicate with their audiences. This provides them with an ability to overcome the limitations of direct communication as the use of media extends their interactions in space and time, which in turn increases organizations' reach. Different media provide different possibilities for communication and the choice of media has often been given extensive attention when organizations are about to set up their communication activities. Alternatives in those situations are plentiful and with the addition of digital technologies the number has increased almost exponentially [6].

Blogs appeared in the late 1990s and have since become a popular online communication activity [7]. Blogs or "weblogs" have several advantages: they can appear in the opposite order and can be updated regularly. One way for organizations to communicate is to use blogs. Blogs can be interpreted as pages related to the internet domain, where on that page the organization can write or load information related to the organization's goals [8].

This study tries to explain and reveal how bloggers become media partners for endorsement of products in a brand, and how the criteria must be met by bloggers so that companies can repeatedly use or hire them. 


\section{RESEARCH METHODS}

This study uses a qualitative approach that is descriptive [9]. The case study method was chosen to carefully investigate the activities and programs related to bloggers who play a role in endorsement of a brand. Data collection was carried out through interviews with relevant

informants: Blogger, Blogger Community Founder, Blogger Agency, and Corporate Communication Staff.

\section{DISCUSSION AND RESULT}

This research tries to explain how companies see and make some adjustments in media relations activities, in this context is involving bloggers as media partners. Many problems arise regarding personalization of bloggers, using appropriate social media channels, and packaging information in a short, easily caught form for bloggers who tend to dominate conversations in relationships among bloggers. Some literature also shows an interest in identifying groups of bloggers who can work with corporates, develop relationships with bloggers and how to maintain the relationships [7].

The influence of bloggers on consumers has been explored widely in various literature as an important aspect in the postmodern era. The increasing power of bloggers on consumers has encouraged academics to conduct several studies on bloggers [10].

\section{Blogger: Transforming New Media Relations}

As explained previously, corporates are experiencing communication disruption in engaging engagement with their public or target audience. In media relations activities, the company must also look at the needs in terms of managing messages to be shared with targeted media partners. Corporate needs a strategy to develop relationship with the media or the so-called media relations. Media relations look at managing communication and relationships with the media, writers, editors, or producers. In general, media coverage of a company has a strong influence on a company's reputation. This research tries to investigate large companies, such as PT Sinarmas, which partners with bloggers as a form of media relations so that in this case the company transforms from old media relations to switch to new media relations. Media relations basically have tools and techniques that are commonly used, namely press releases, press conferences, interviews, and media monitoring \& research [11].

In the current era of new media, these tools are not abandoned but modified according to company needs. According to Haris Maulana, Social Media Specialist, from the Corporate Communication Division of PT Sinarmas, a well-known company engaged in property, said:

"Nowadays time has changed, including how companies develop media relations strategies, we used to choose more in print media, but now we must be able to adjust to the public segment that prefers online media or social media, our company uses what is called Public Relations Value (PR Value), which is how we equalize the cost of promotion or advertising on the mainstream media with new media, but we still use basic tools, preparing press releases, media monitoring, press conferences, for example by organizing events, where media andbloggers are invited, then we do some analysis, so that by one event, we can reach several strategies, and we call advertising efficiency and promotion costs because the corporate has blogger partners".

Based on interviewing with Haris Maulana as acorporate communication practitioner, there are several points related to the transformation and adjustment of switching from old media relations to new media relations:

1. New Media relations does not leave basic tools and techniques. The corporates still have their press releases, which are then called social media news releases. Likewise for bloggers, the company still prepares press releases which are then reproduced by bloggers from their angle or perspective, so that this is what differentiate between bloggers and journalists, that is, the blogger's narrative is subjective, in contrast to journalists who write news by following the rules of journalism and be objective according to the source.

2. A new media relation that utilizes technology in new media makes it possible for corporates to increase engagement with the target audience. Bloggers certainly take advantage of the power of social media they have, so one of the considerations of companies pitching for bloggers is to see the KPI (key performance indicator) for their social media, which includes aspects of interactivity (like, comment, viewer) and the number of followers.

3. New media relations inevitably encourage transformation and adaptation in corporate communication strategies, as, for example, what has been done by PT Sinarmas. The company focuses on target consumer, by promoting a Millennial House, meaning that the tagline raised is MILLENIAL, where millennial terminology is a productive generation group which certainly requires house in accordance with their soul and character.

4. The existence of the value of personal relationships (interpersonal relationship value) between bloggers and the corporate, or PR practitioners, or the corporate communication department will be more likely to succeed in making publications for the corporate, because there is emotional closeness. When relations between the two parties are more mature, it will increase mutual understanding between the two parties. For organizations, this closeness will certainly be easier to raise awareness (awareness) of bloggers who act as media partners to make the organization a communication preference for the target public with their power of narration in their blog content.

According to Mubarika Darmayanti from PT Byond, an agency that provides bloggers for the corporates, said:

"Blogger is a profession in someone who has a passion and a hobby of conveying opinions, knowledge, and information through blogs. A blogger has an added value that is not owned by other online media portals, they have strong opinion that can "lead" readers without giving ads ". (Interview with Mubarika Darmayanti, who comes from PT Byond). 


\section{Blogger Criteria and Effectiveness for Endorsement}

The organizations need bloggers for publication and maintain reputation. The selected blogger partner must have some standard criteria, as stated by the informants, they are

1) Having a blogging portal, at least 1 year old; 2) High Domain Authority (DA) and Page Authority (PA); DA is a reference for search engines in ranking a website or blog. Search engines like Google will rank a site based on several things, domain age, domain popularity, and domain size. Meanwhile, PA is the space in DA that is given value by search engines; 3 ) Blogs that are owned are not free domains or must be paid because this shows the credibility of a blogger, 4) Traffic pages above 100 unique view (UV) per day, and 5) Having active social media. Bloggers who can fulfil the needs and targets of the organizations are seen from their KPI. SEO is now a major factor in targeting bloggers, when their posts are on page 1 , the more people want to read (page rank).

In determining the blogger to be recruited by the corporates, they go to the Agency, which can connect between the company and the blogger who meets the criteria needed by the corporate. In an interview with Founder Micro Blog Communication (MB Communication), which provides the Indoblognet website, Kartina Ika, said:

"Agency builds enthusiasm in educating bloggers, for example, reinforces bloggers to improve their ability in writing, have a target number of articles that can be posted on their blogging pages, bloggers must have SEO competence, so that their writing will be on the initial page in the search engine, so that more people will read"

Ika explained that ideally, bloggers are not only endorser, but they also carry out several roles, because essentially, the blogger is a messenger of information, so he can play the role of a public relations and marketer, so that when there are consumers asking things related to the product, then bloggers can explain it. Bloggers are also targeted to be consumers (target market), meaning that when bloggers review or endorse product, psychologically they are compelled to buy or consume the products that have been reviewed.

If the criteria to become productive bloggers are able to do repeating in endorsement, then it can be said that bloggers are effective in corporate media relations because of the following things:

1. Unlike online media portals that display advertisements or advertorials based on an agreed broadcast schedule, the blogger's writing about a product will stay forever in the blog and even become a reference for other blog posts.

2. Utilizing the services of bloggers in the promotion is like spreading "spider web" on the internet. Therefore, when hiring bloggers, for example 10 people, 1 or 2 posts from them can be indexed on page 1 in the Google search engine as reliable reference information based on keywords or taglines that are echoed by the organization.

Then what about the bloggers who later became media partners for the company, following the results of an interview with Ani Berta, a blogger and also the Founder of ISB (Indonesia Socio Blogpreneur):

"Being a blogger must be strong in terms of social media engagement, the quality of articles or writing (plot, angle, and selection of diction), the convenience of the company because of the disciplined attitude shown by bloggers, for example timely posting articles according to the agreement".

In addition, informants from several bloggers who were successfully interviewed were: Wahyu Komala (nice lifestyle), Gita Siwi (lifestyle), Ipul Soedibjoe, travelblogger (www.siipuljalanjalan.com), and tutyqueen (www.tutyqueen.com) revealed that they got some positive things by undergoing activities as a blogger: 1) expanding their networking, 2) more followers in social media, 3 ) increasing knowledge and insight, 4) opening opportunities to get jobs from the brand.

\section{CONCLUSION}

New media enables corporates to transform media relations activities through a variety of online and social media, including bloggers. The involvement of bloggers in media relations is carried out by various criteria that meet the corporate's needs, so that the endorsement can be more effective and efficient.

The criteria needed by the corporates are related to social media engagement, interactivity and the indicators in the search engine (browser). By the appearance of blog articles on the earlier page of a search engine, the better the quality of articles written for the endorsement of a product or brand. Therefore, bloggers and corporates are a mutualism relation, and being a blogger must improve the quality of writing and SEO capabilities, whereas the corporates are also more selective in finding bloggers who have strong engagement with social media.

\section{ACKNOWLEDGMENT}

I would like to express my gratitude to Prof. Dr. Suswandari as the Chair of Research dan Development Center of UHAMKA for supporting, motivating and guiding this research.

Also thanks to all my informants, Ms. Mubarika Damayanti (PT Byond), Ms. Kartina Ika (MB Communication), Mr. Haris Maulana (PT Sinarmas), Ms. Ani Berta (Founder of ISB), and the bloggers who were willing to answer my research questions for completing the data.

\section{REFERENCES}

[1] Ganiem, Leila Mona and Kurnia, Eddy, "Komunikasi Korporat, Konteks Teoritis dan Praktis", Prenadamedia Group, Jakarta, 2019

[2] Supa, W. Dustin "The Academic Inquiry of Media Relations as both Tactical and Strategic Function of Public Relations", Research Journal of The Institute of Public Relations, Vol 1, No. 1, 2014, pp. 115 .

[3] Zoch, LM., and JC Molleda, JC, "Building a theoretical model of media relations using framing, information subsidies, and agendabuilding", in "Public Relations Theory II", Botan, Carl, \& Hazleton, Vincent, Eds.New York: Lawrence Elbraum Associates, 2006

[4] Zerfass, A, Verci, D, and Wiesenberg, M, "The dawn of a new golden age for media relations? How PR professionals interact with the mass media and use new collaboration practices Author(s), Public Relations Review, Vol 42 (4), Elsevier, pp. 499-508.

[5] Waters, Richar D, Tindall, Natalie T.J, and Morton, Timothy S, "Media Catching and the Journalist-Public Relations Practitioner Relationship: How Social Media are Changing the Practice of Media Relations", Journal of Public Relations Research, Vol. 22(3), Routledge, 2011, pp. 241-264 
[6] Fredriksson, Magnus and Pallas, Josef, "The localities of mediatization How organizations translate mediatization into everyday practices", Dynamics of mediatization, Springer, 2017.

[7] Walden, J.A., Bortree, D, and Distaso, M, "Public Relations Review Reconsidering the public relations professional-blogger relationship: A coorientation study, 41, 2015, pp.526-528

[8] Nurhablisyah, "Blog sebagai Bagian dari Media Relations : Peran Blog untuk Menjembatani Tujuan Organisasi” : DEIKSIS Vol. 03/03, 2011, pp. 276-289

[9] Neuman, W. Lawrence, "Metodologi Penelitian Sosial: Pendekatan Kualitatif dan Kuantitatif', Edisi 7, Indeks, Jakarta, 2016.

[10] Balabanis, G., \& Chatzopoulou, E.,"Under the influence of a blogger: The role of information - seeking goals and issue involvement", (1948), 2019, 1-12. https://doi.org/10.1002/mar.21182

[11] Cornelissen, Joep, "Corporate Communication : A Guide to Theory and Practice”, London : Sage Publication Ltd., 2009. 